https://helda.helsinki.fi

\title{
How arguments are justified in the media debate on climate change in the USA and France
}

\section{Ylä-Anttila, Tuomas}

2014-12-31

Ylä-Anttila , T \& Kukkonen , A 2014 , ' How arguments are justified in the media debate on climate change in the USA and France ' , International Journal of Innovation and Sustainable Development, vol. 8 , no. 4 , pp. 394-408 . https://doi.org/10.1504/IJISD.2014.066658

http://hdl.handle.net/10138/153448

https://doi.org/10.1504/IJISD.2014.066658

submittedVersion

Downloaded from Helda, University of Helsinki institutional repository.

This is an electronic reprint of the original article.

This reprint may differ from the original in pagination and typographic detail.

Please cite the original version. 


\title{
How arguments are justified in the media debate on climate change in the USA and France
}

\section{Tuomas Ylä-Anttila* and Anna Kukkonen}

\author{
Helsinki Research Group for Political Sociology, \\ Department of Social Research, \\ University of Helsinki, \\ P.O. Box 18, 00014, Finland \\ E-mail: tuomas.yla-anttila@helsinki.fi \\ E-mail: anna.k.kukkonen@helsinki.fi \\ ${ }^{*}$ Corresponding author
}

\begin{abstract}
This paper examines the differences in the values that are evoked to justify arguments in the media debate on climate change in USA and France from 1997 to 2011. We find that climate change is more often discussed in terms of justice, democracy, and legal regulation in France, while monetary value plays a more important role as a justification for climate policy arguments in the USA. Technological and scientific arguments are more often made in France, and ecological arguments equally in both countries. We argue that understanding these national differences in argumentation at least partly as reflections of deep-seated cultural conceptions about what is worthy may help in understanding why disagreement persists in the global politics of climate change.
\end{abstract}

Keywords: climate change; climate politics; global warming; media; content analysis; climate justice; justification; justifications analysis; sustainable development; USA; France.

Reference to this paper should be made as follows: Ylä-Anttila, T. and Kukkonen, A. (2014) 'How arguments are justified in the media debate on climate change in the USA and France', Int. J. Innovation and Sustainable Development, Vol. 8, No. 4, pp.394-408.

Biographical notes: Tuomas Ylä-Anttila, $\mathrm{PhD}$, is a Research Fellow at the Department of Social Research, University of Helsinki. He specialises in moral and political sociology, climate politics, civil society and the media.

Anna Kukkonen is a doctoral candidate at the Department of Social Research, University of Helsinki. She works on media coverage of climate politics in a comparative perspective.

This paper is a revised and expanded version of a paper entitled 'Civil society organisations and cultural repertoires of evaluation in the media debate on climate change: comparing France and the United States' presented at the Conference Environment, Technology and Sustainable Development, Gwalior, India, 2-4 March, 2014. 


\section{Introduction}

The idea of justice in mitigating and adapting to climate change has received much attention in the academic literature, civil society, and international negotiations. Scholars in political philosophy and law have examined the different issues related to distributive, retributive, and procedural justice that are implicated in climate change adaptation and mitigation (Posner and Weisbach, 2010; Parks and Roberts, 2010; Soltau, 2009). A social movement for climate justice has spread around the world and includes long-established global civil society networks like the Climate Action Network and the more recent Climate Justice Now!, whose demands and tactics seem more radical (Reitan and Gibson, 2012; Goodman, 2009). The idea of common but differentiated responsibilities in climate change mitigation institutionalised one key idea of justice, the idea of historical responsibility, into the first international treaty to regulate climate change, the Kyoto Protocol. The protocol mandates binding commitments to reduce greenhouse gas emissions only to the rich industrialised countries that bear more responsibility for historical emissions of those gases (the so-called Annex I countries). The just division of the burden of climate change mitigation and adaptation has been one of the principal stumbling blocks in the failed efforts to negotiate a new global treaty on climate change to replace the Kyoto Protocol.

In this light, it is somewhat surprising that the studies of media reporting on climate change politics, itself a rapidly growing field of research, has hardly looked at how justice claims, and more generally justifications based on different understandings of what is morally worthy, figure in the public debate on climate change. Even more surprisingly, a study that did look for moral framings of climate change in the media found that there were none; climate change was mostly framed in terms of its consequences (Dirikx and Gelders, 2010).

In this paper, we address this gap in the literature by comparing the justifications given for arguments in the media debate on climate change in newspapers in France and the USA. We argue that the seeming absence of moral argumentation found by Dirikx and Gelders is a result of the rather narrow definition of moral talk that they use. Building on Boltanski and Thévenot's theory of justification, we propose a wider definition of moral argumentation by looking at the different worlds of justification that the actors use to support their arguments. We operationalise justification theory for the purpose of analysing media debates by introducing a new methodological approach we call justifications analysis.

This innovative approach offers a new way to study contested issues in global climate policy and the interactions between cultural discourses and policy positions. Its relevance to the politics of climate change stems from the fact that it helps us understand diverging positions of different countries in the arena of global climate politics from a new perspective. We argue that these differences are, at least partly, reflections of deep-seated cultural conceptions about what is worthy. Understanding the differences this way may also help in understanding why disagreement persists in the global politics of climate change.

There are several reasons for selecting USA and France as our case studies. The first one is that the USA and the European Union, where France is one of the strongest agenda setters, represent two important negotiating blocks in the global politics of climate change. These two blocks have, so far, taken diverging positions in the negotiations, especially towards the third influential negotiating block, the developing countries. 
The EU has strongly pushed for a global treaty and taken commitments to reduce GHGs, while the USA has refused to take on any binding reduction commitments, at least if the large emerging economies (particularly China and India) are not willing to do the same. Thus, understanding the differences of the moral points of view that are considered relevant in each country may help in understanding what is at stake in the negotiations for a global climate treaty. Second, there is some literature comparing the political cultures of these two countries from the perspective of moral justifications that we can use to construct our research hypotheses (see below). Finally, third, media reporting on climate change in these two has been compared with material reaching until 1997 (Brossard et al., 2004), so we have the opportunity to discuss our findings on more recent material in the light of the earlier ones.

The literature on media reporting on climate change in the USA is, by now, quite extensive. Much of it has focused on reporting climate science, especially the disproportional influence of the 'denialists', who present themselves as experts and deny the consensus reached by climate science (IPCC, 2007) that anthropogenic climate change is real (e.g., Antilla, 2005; Boykoff and Boykoff, 2004). There are two reasons for this overrepresentation of denialists in the US media. First, the fossil fuel industry has been keen to fund denialist think tanks (Antilla, 2005; McCright and Dunlap, 2000, 2003) and second, the journalistic norm of balance works in this case to overamplify the denialists' visibility (Boykoff and Boykoff, 2004, 2007). France, too, has had its share of denialists, notably after 2009 (Jurdant and Poupardin, 2010) but they have not gained as much visibility and have not had strong contacts to fossil fuel industries like the USA (Aykut et al., 2012, p.166).

Comparing the cases of USA and France until 1997, Brossard et al. find three main differences between the two countries. First, US reporting tends to focus on the consequences of climate change, while the French reporting focuses more on climate change politics. Second, the variety of speakers in the US debate is wider. Third, in France the coverage does not follow an issue attention cycle observed by earlier studies on the USA. The authors attribute all these differences to differences in journalistic cultures: the US press is more oriented towards objective reporting of facts, while the French press is more engagé, oriented towards taking a political stand.

Mormont and Dasnoy (1995) also find the French debate politically charged, at least more than it is in Belgium and Germany. They attribute this difference to the different structures of the journalistic, scientific, and NGO fields in the three countries. Aykut et al. (2012) explain the contours of the French media debate on climate change between 1990 and 2010 by referring to similar structural factors and their changes. Caillaud et al. (2011) confirm the strong political orientation of French climate change coverage by comparing reporting of the Bali 2007 COP in France and Germany.

Of the two studies that have looked for moral argumentation in either of our case countries (Dirikx and Gelders, 2010; Caillaud et al., 2011), both studied France and neither found moral arguments presented there (Caillaud et al. did find some in Germany). Both of these studies, however, defined moral argumentation somewhat narrowly, to include mainly references to religion or "specific social prescriptions about how to behave" (Dirikx and Gelders, 2010, p.6).

In the following sections, we will argue that a wider definition of moral argumentation is useful in analysing media debates on climate change and understanding differences in national political cultures that shape these debates. Our results highlight a tendency to emphasise the value of equality, democracy and legal regulation in France, 
and a tendency in the USA to justify arguments based on market worth. Technological and scientific arguments are more often made in France, and ecological arguments equally in both countries.

\section{Analytical perspective and hypotheses}

Boltanski and Thévenot's (2006) justification theory begins with the idea that to convince their opponents in a dispute, people are obliged to justify their position with references to the common good. In modern societies, there is a plurality of conceptions of the common good that may be wide, but not unlimited. The authors find seven 'worlds of justification', each one based on a different conception of the common good, and thus, a different measure of what is worthy.

Based on our preliminary reading of the research material, we argue that four of these seven worlds of justification are of particular relevance to the media debate on climate change. First, civic justifications emphasise the value of democratic decision-making procedures, such as deliberation by democratic states within the UN system, and the just distribution of the burden of climate change mitigation and adaptation.

Second, market justifications may be used, either to oppose ecological arguments by arguing that climate change mitigation is too expensive, or to propose market solutions to the problem of climate change, such as carbon trading. In arguments stemming from the market world, then, the measure of worth is money, and it is believed that market mechanisms are efficient in producing common good.

Third, industrial justifications, which place value on technological progress and scientific measurement, and which are based on the belief that technological innovation and scientific calculations are the most efficient base to battle against climate change, are likely to be used. Finally, ecological justifications determine the worth of actors and policies by evaluating their contribution to the well-being of the natural environment (Moody et al., 2000; Lafaye and Thévenot, 1993).

These worlds of justification provide a kind of cultural toolkit for moral argumentation, a set of principles that can be assumed to be recognised by both the claimsmakers and the addressees that they seek to convince. The differences in the usage of the different worlds of justification and the ways in which they are combined in different countries reflect differences in political cultures (Lamont and Thévenot, 2000).

In the following sections, we formulate a hypothesis on the differences between France and the USA with regard to each of the four worlds of justification discussed above: civic, market, industrial, and ecological. We then proceed to test these hypotheses first quantitatively, and then substantiating our findings through in-depth qualitative analyses.

First, Mormont and Dasnoy (1995) and Caillaud et al. (2011) both argue that the climate change debate in France is more political in nature than in the USA, where, as we have seen, the debate over the certainty of climate science has dominated instead. Moody et al. (2000) show that in the local environmental disputes they analysed, reliance on civic justifications, which invoke democracy and equality as the privileged measure of the common good, is more common in France than in the USA. Moving from climate change and other environmental disputes to ones in city-level politics more generally, 
Luhtakallio (2012) finds that civic justifications seem to dominate French political debates more generally. We therefore hypothesise that

H1: Civic justifications, based on seeing the common good in terms of democratic regulation and equality, are more common in France than in the USA, and are more readily combined with other justification types.

Second, Zehr (2009) has observed that the US press presents "an environmental/ economic hybrid frame", that is, presents a picture where economic growth and environmental protection go hand in hand. This leads us to expect the US debate to show a higher prevalence of market justifications, invoking the common good in terms of money and the desirable society as a materially affluent one. Moody et al. (2000) show that market justifications are more important in USA than in France in other environmental disputes besides the one on climate change. In the USA, market justifications also seem to be more readily combined with other types of justifications, such as civic ones, as in the case of the Rotary charity activities studied by Camus-Vigué (2000). We hypothesise, therefore, that

H2: Market justifications, based on seeing the common good in terms of money, are more common in the USA than France, and are more readily combined with other types of justifications.

Third, Moody et al. (2000) show that technological and scientific justifications are more important in France than in the USA. In the environmental disputes they study, the contention in the French case is focused on arguments over technical efficiency and infrastructure planning, reflecting the well documented presence of an 'engineering mentality' and 'technocratic' approaches in that country (Jasper, 1990; Lamont, 1992). We hypothesise, therefore, that

H3: Justifications based on seeing the common good in terms of scientific and technological progress and efficiency, are more common in France than in the USA.

Finally, ecological justifications, that is, appeals to the common good defined as wellbeing of the natural environment are likely to play an important role in the public debate on climate change. We see no reason, however, to expect that claimsmakers in either of the countries would resort to these justifications more often than in the other. We hypothesise, thus, that

H4: There are no significant differences in the frequency of ecological justifications between France and the USA.

\section{Methods and materials}

We have operationalised justification theory for the purposes of media content analysis by introducing a method we call justifications analysis (Gladarev and Lonkila, 2013; Luhtakallio, 2012; Luhtakallio and Ylä-Anttila, 2011; Ylä-Anttila, 2010). This method is a variant of political claims analysis developed by Koopmans and Statham (1999). The unit of analysis is a claim, defined as a unit of action in the public sphere. A claim can be a comment in an interview or a public speech, a demonstration or other action 
whose purpose is to influence public debate. One newspaper article may, therefore, contain several claims by several actors.

Unlike political claims analysis that employs a fairly standard notion of framing arguments, justifications analysis focuses on more specifically defined ways of supporting claims. We define moral justification as supporting a political claim by appealing to some form of common good, assumed by the speaker to be shared, at least to some degree, by the addressee of the claim. We classify these justifications according to the scheme proposed by Boltanski and Thévenot (2006). These authors show that these 'worlds of justification' have a long history in the tradition of western moral philosophy, and that the same moral principles are often used in moral disputes today.

Our research material consists of the reporting of the UN climate conferences (COPs) in the New York Times and Le Monde. The papers occupy a somewhat similar position in the journalistic field of their respective countries, being considered quality papers with a strong international orientation and a political position slightly left of the centre. Thus, they can be expected to

- cover international events like the COPs

- be comparable with each other

- provide material comparable with earlier studies, notably Brossard et al. (2004) comparing the same two papers for an earlier time period (1987-1997), but also with other studies on media coverage of climate change, as most of them have focused on quality papers (e.g., Dirikx and Gelders, 2010; Boykoff and Boykoff, 2004; Carvalho, 2007).

For the first stage of the analysis (quantitative), we identified the claims presented in the articles and the primary justifications that were used to support them. For the identification of the claims, we used the codebook developed by Koopmans (2002). For identification of justifications, we trained our coders and developed our own codebook $^{1}$ through coding a sample of 71 articles reporting on the COP 14, that is, material not included in the sample analysed here. We held five meetings, for which each of the six coders coded a set of 10-15 articles. Results were compared, and difficult coding decisions that were identified contributed to updating the rules written in our codebook. Thus, an updated version of the codebook was used for each new set of articles discussed in the consequent meeting. In the fifth meeting we recorded the results from each coder and calculated intercoder reliability coefficients following the model used by Koopmans and Statham $\left(2010\right.$, p.53). ${ }^{2}$ Reliability easily satisfied conventional standards. For instance, the reliability coefficient for claim identification was 0.92 and for coding the primary justifications 0.95 .

The material was then coded using a qualitative content analysis (QCA) software, from which a data matrix for the quantitative analysis was exported and analysed with statistical software. In a further qualitative stage of analysis we used QCA and a more extensive set of codes to gain deeper understanding of the different combinations of the justifications used and the roles of different actors in the debate.

We began our sampling with a period of four weeks of reporting on the Copenhagen COP 15 , beginning one week before the conference, identified by earlier studies as the high point of reporting on climate change around the world (Schmidt et al., 2013), and searched the electronic archives of both newspapers with a set of keywords. ${ }^{3}$ We then added similar four-week samples of the Durban COP 17 in 2011 and 
Kyoto COP 3 in 1997 to add temporal depth to our sample. The total number of articles returned by this procedure was 115 for the New York Times and 474 for Le Monde. As the number of articles in Le Monde was so much higher, we decided to follow the approach often used in such cases (e.g., Vetters et al., 2009) of coding only every other article in that newspaper. This resulted in the final sample of 237 articles containing 386 claims for Le Monde and 115 articles containing 433 claims for New York Times. The articles in New York Times were, on average, significantly longer, which resulted in a much higher number of claims reported per article than in Le Monde.

\section{Results}

\subsection{Justifications calling for equality, democracy, and legal regulation}

As predicted by our first hypothesis, justifications appealing to civic worth, that is, common good defined in terms of equality, democracy, and legal regulation are more common in France than in the USA. Table 1 shows the proportions of the different justifications used in the two countries.

Table 1 Proportions of justifications by country

\begin{tabular}{cccc}
\hline & USA $(N=433)$ & $F R(N=386)$ & Difference FR-USA \\
\hline Civic total & 0.33 & 0.44 & $0.11^{* * *}$ \\
Civic justice & 0.06 & 0.14 & $0.08^{* * *}$ \\
Civic democracy & 0.21 & 0.24 & 0.03 \\
Civic legal regulation & 0.02 & 0.06 & $0.04^{* * *}$ \\
Market total & 0.10 & 0.06 & $-0.04^{* *}$ \\
Market over ecology & 0.03 & 0.01 & -0.02 \\
Market and ecology & 0.07 & 0.05 & -0.02 \\
Technoscientific total & 0.13 & 0.21 & $0.08^{* *}$ \\
Greentech solutions & 0.05 & 0.06 & 0.01 \\
Other technoscientific & 0.08 & 0.15 & 0.07 \\
Ecology total & 0.11 & 0.09 & -0.02 \\
Ecology over market & 0.02 & 0.01 & -0.01 \\
Other ecology & 0.09 & 0.08 & -0.01 \\
\hline
\end{tabular}

$* p<0.05, * * p<0.01, * * * p<0.001$ based on a Chi-Square Test (two-sided tests).

Civic justifications are the most common kind in both countries $(33 \%$ in the USA and $44 \%$ in France), and most of them are made in support of the process of interstate negotiation and democratic decision-making in the $\mathrm{UN}$ as a possible solution to the problem of climate change. While arguments generally supporting the UN process are very common in both countries, there is a significant difference in the frequency of calls for legal regulation of climate change, that is, a legally binding international treaty. Justifications placing value on the idea of legal regulation are three times as frequent in France as they are in the USA. 
We also coded for the origin or scope of each claimsmaker (domestic/other nation/international). Table 2 presents the same figures as Table 1, but for domestic speakers only (i.e., only French claimsmakers in the French media and only American claimsmakers in the USA). In these figures, the difference referred to above is even more pronounced: French claimsmakers in the French media are five times as likely to argue for legal regulation of climate change (10\% of claims) than American claimsmakers in the US media (2\%). The fact that justifications favouring legal regulation are more often made by French actors in France and foreign actors in the USA suggests that favouring legal regulation is a feature of French political culture.

Table 2 Proportions of justifications by country, domestic actors only

\begin{tabular}{lccc}
\hline & USA $(N=186)$ & $F R(N=130)$ & Difference FR-USA \\
\hline Civic total & 0.30 & 0.44 & $0.14^{* * *}$ \\
Civic justice & 0.03 & 0.09 & $0.06^{*}$ \\
Civic democracy & 0.25 & 0.25 & 0.00 \\
Civic legal regulation & 0.02 & 0.10 & $0.08^{* * *}$ \\
Market total & 0.15 & 0.03 & $-0.12^{* * *}$ \\
Market over ecology & 0.05 & 0.00 & $-0.05^{* * *}$ \\
Market and ecology & 0.10 & 0.03 & $-0.07^{*}$ \\
Technoscientific total & 0.17 & 0.30 & $0.13^{* *}$ \\
Greentech solutions & 0.09 & 0.13 & 0.04 \\
Other technoscientific & 0.08 & 0.17 & $0.07^{*}$ \\
Ecology total & 0.09 & 0.10 & 0.01 \\
Ecology over market & 0.02 & 0.02 & 0.00 \\
Other ecology & 0.07 & 0.08 & 0.01 \\
\hline
\end{tabular}

$* p<0.05, * * p<0.01, * * * p<0.001$ based on a Chi-Square Test (two-sided tests).

Typically, civic justifications are used by civil society organisations, journalists, and politicians. But in a manner interestingly reflecting the difference between the two countries, in France economic organisations too find it sometimes useful to appeal to civic values in a way that would be difficult to imagine in the USA. A lobbyist for French beef producers begins his letter to the editor with reference to natural science and measurement ('industrial worth'), by arguing that pasturage acts as a carbon sink and partially cancels out the effects of the greenhouse gas methane produced as a by-product of beef production. But above all, he stresses the civic worth of the French system of beef production, describing it as a 'citizen project':

\footnotetext{
"Our model of beef production is an excellent territorial, environmental, cultural, economic and social project; it is a citizen project (projet citoyen) where the industry is committed to sustainable beef." (Denis Sibille, President of Association Interbev, Le Monde 22.12.2009)
}

Claims that take up issues of distributive justice in relation to climate change constitute a minority of claims in both countries, but are more than twice as common in France (14\%) than in the USA $(6 \%)$. In both countries, intergovernmental organisations and international NGOs play an important role in making justice claims. In France, however, the variety of 
actors making justice claims is much higher, and the idea of historical responsibility of the long-industrialised countries for climate change is accepted by the government too. This is also reflected in the global negotiating arena, where France has taken a relatively positive or at least mediating position towards the demands of developing countries.

"Europe and the rich countries, we must accept that our responsibility is heavier than others' ... our engagement must therefore be stronger." (President Nicolas Sarkozy, Le Monde 17.12.2009)

The USA negotiating position has oscillated between the relatively accommodating stance of the Clinton/Gore administration in 1997 to pulling out of the Kyoto Protocol and the COP negotiations entirely by Bush in 2001 to the Obama administration participating in the talks again. However, the notion of historical responsibility of the early industrialisers for their past emissions is still rejected by the US negotiators at the Copenhagen COP 2009:

\footnotetext{
"I actually completely reject the notion of a debt or reparations or anything of the like...For most of the 200 years since the Industrial Revolution, people were blissfully ignorant of the fact that emissions caused a greenhouse effect." (Todd Stern, the chief negotiator of the US government, New York Times 9.12.2009)
}

In addition to the issue of justice between developing and developed countries, in the French debate, several claims are also made for restructuring the highly developed countries in ways that are both ecologically and socially sustainable. In the USA, the government does promise to contribute to the Green Climate Fund, but rather than on pondering the moral responsibility behind the idea of establishing such a fund, the debate is focused on pragmatic details of implementing the idea.

\subsection{Market justifications}

In line with our second hypothesis, the US debate includes more references to monetary value as the kind of common good that ought to be considered the most important when discussing climate change. $10 \%$ of claims in the USA and six in France are justified in market terms. Again, this difference becomes more pronounced when we look at domestic actors only. In France, only 3\% of French speakers justify their argument in this way, contra $15 \%$ of American speakers in the USA.

Arguments that oppose ecological and monetary worth, and assert the importance of the latter over the former, are marginal in France ('market over ecology', 1\%, zero for French actors), but do play some part in the US debate (3\%, five for American actors). Most of these arguments come in one burst after the Kyoto negotiations in 1997 from conservative politicians and related research institutes.

\footnotetext{
"Protecting our environment is an honorable goal", Representative Bill Paxon, a fast-rising Republican star from New York, said. "But we must ask ourselves an equally important question: "Can we afford to destroy our children's economic future in the process?" (New York Times, 1997)
}

While there is another attack against climate action in the USA around the Copenhagen conference in 2009, this one is no longer based mainly on saying that acting on climate change is too expensive. Rather, it operates by denying the existence of the whole phenomenon and questioning the validity of climate science based on e-mails stolen 
by hackers from the climate scientists at the University of Anglia (the so-called Climategate incident). The dispute here is no longer fought in market terms, but in terms of justifications that invoke the value of scientific knowledge and measurement, instead of monetary value.

More common in both countries than the arguments opposing ecological and monetary worth are arguments that see the two go hand in hand ('market and ecology', $7 \%$ in the USA, 5 in France). Our qualitative analysis shows that at least two kinds of these arguments: those based on monetary worth alone, and those based on a combination of ecological and monetary worth, seeing climate change as a business opportunity.

The first kind calls for action on climate change with the justification that inaction is more expensive in the long run than action now. This argument, based solely on monetary value and thus made to appeal also to those who are not moved by ecological values as such, was famously made by the Stern Review on the Economics of Climate Change (Stern, 2006). While this argument is sometimes presented in France too, it is illustrative of the US debate that there the argument can be made by a coalition of CSOs and multinational businesses, who have commissioned a study from an international consultancy firm and underline they are targeting specifically those people to whom ecological values do not matter:

\begin{abstract}
"A large share of the reductions [in $\mathrm{Co} 2$ emissions] could come from steps that would more than pay for themselves in lower energy bills for industries and individual consumers, the report said, adding that people should take those steps out of good sense regardless of how worried they might be about climate change...The study, released yesterday in Washington, was conducted by McKinsey \& Company for DTE Energy, Environmental Defense, Honeywell, National Grid, the Natural Resources Defense Council, Pacific Gas \& Electric and Shell." (New York Times, 2009)
\end{abstract}

A somewhat more complicated relationship between monetary and ecological worth is posited by the second kind of argument, based on the idea that actions designed to fight climate change are not a cost at all, but rather, a business opportunity. Creating ecological value is not only a good in itself, but also results in the creation of monetary value at the same time. This argument is found in both of the countries. Perhaps the most eloquent version is put forward by President Obama, commenting on the Copenhagen COP:

\footnotetext{
"We're going to be the guys who are producing wind turbines, and we're going to be the folks who are producing solar panels on rooftops...it produces jobs that can't be exported; it reduces our dependence on foreign oil; it is good economics; it will increase our exports - oh, and by the way, it also solves the climate problem." (Obama, New York Times, 2009)
}

\title{
4.3 Techno-scientific justifications
}

Our third hypothesis expected the French debate to include more justifications seeing the common good in terms of planning, scientific measurement, and technological progress ('industrial worth'). The hypothesis is supported, with $21 \%$ of claims in France and $13 \%$ in the USA using this justification. Again, this difference becomes more pronounced when we look at the figures for domestic actors only (Table 2, 30\% for France and 17 for the USA), supporting our argument that arguing more often in terms of 'industrial worth' is part of the French way of conducting political argumentation. 
Our qualitative analysis shows that there is another important difference between USA and France in the use of this kind of justifications: in the USA, they are almost without exception combined with arguments referring to monetary value (market justifications), while in France, a more common combination is a reference to the capacity of the democratic state or another governing body such as the EU or institutions of global governance to steer society towards greener production and technology (civic justification).

For the USA, the examples presented in the above discussion of market justifications, with President Obama presents green technology as 'good economics' and the coalition of CSOs and corporations argues that $\mathrm{CO} 2$ reductions would "more than pay for themselves" illustrate this point. Almost all other arguments valuing technology also make reference to monetary value. The EU "needs to keep the prospects of a global deal alive so that European business leaders and voters believe they are on track to take advantage of green technology markets of the future"; what is needed is "an agreement which sets tough, realistic global-emission reduction goals while harnessing market forces to lower costs, foster technological development and insure economic growth"; and converting a school to use geothermal energy "reduces greenhouse gas emissions by $40 \%$ compared with conventional technology, and Dorchester County, Md., expects to save $\$ 400,000$ in energy and maintenance costs at the school in the next 20 years". Whether it is arguing for a global deal that is geared towards generating more green technology or local uses of emissions reduction technology, it always needs to be supported by a justification based on market worth.

In France, the connection between green technology and market growth is sometimes made as well, but more often in Keynesian terms, with reference to a state intervention in the markets rather than by relying on market forces alone or giving estimated sums of money as proof for one's justification. Thus, the stimulus packages proposed by states to counter the current economic crisis are seen as an opportunity for green technology investment:
"[There is a need], on the one hand, to restart and reinforce the economic machine by massive investments; and on the other, to protect the environment by directing these investments to environmental action. The stimulus packages in all countries could be an occasion to advance a green economy." (Le Monde, 2009)

For many in the French debate, market forces alone are not capable of promoting green technology investment: "It is clear, pace the claims of those who support the liberal orthodoxy, that these questions go beyond the strategies of individual enterprises and depend more on the industrial policies of the member states [of the EU]". The EU is also called to "do its share in supporting technological progress" and to "establish a carbon tax".

One idea unique to the French debate is the strengthening of the capacity of the system of global environmental governance by establishing the World Environmental Organisation. This proposal has been discussed in international fora for decades now - the last time it was on the agenda but was rejected was at the Rio+20 UN environmental conference in 2012. In the US debate this idea is not discussed at all. In France the right-wing president Sarkozy wowed to 'fight until death' to defend the proposal, and the president of a multinational corporation goes to great lengths to assert the important role of states and the desirability of a supranational regulator: 


\begin{abstract}
"The public powers of different countries, through environmental regulation and incentives and support for innovation, have an essential role to play...especially in protecting the interests of the poorest countries. This requires that the countries decide to establish an international environmental organisation.” (Businessman, Le Monde, 2009)
\end{abstract}

The desirability and feasibility of political governance of the problem of climate change is, in France, not something promoted by leftist politicians or idealist CSOs, but something that seems to be accepted quite widely.

Our fourth hypothesis, stating that there is no significant difference in the use of ecological arguments in the two countries is also supported. The frequency of explicitly ecological arguments in both countries suggests that saying that climate change is an ecological problem is no longer news in the post-1997 period studied here. Instead, especially in the context of the UN COPs, the issues of justice and democracy related to climate change, its economic costs and possible benefits, and scientific measurement and technological control - the other three justification types that we have discussed - are brought more to the fore.

\title{
5 Conclusions
}

We began by observing that while there is a significant academic and political debate on the moral implications of climate change and climate policy, conventional approaches to the study of media frames do not always seem to be sensitive to the moral evaluations presented in the media debate on climate change. We proposed an alternative approach to the study of moral talk, defining it as giving justifications that appeal to some form of common good, assumed by the speaker to be shared, at least to some degree, by the addressee of the claim.

We found that climate change is more often discussed in terms of justice, democracy, and legal regulation in France, while monetary value plays a more important role as a justification for climate policy arguments in the USA. Technological and scientific arguments are more often made in France, and ecological arguments equally in both countries.

Almost all of these differences become more pronounced when we limit the analysis to domestic actors only. ${ }^{4}$ This means that a part of the less typically French arguments in the French media are actually put forward by foreign actors, and the same goes for the less typically American arguments in the US case. This finding, thus, supports our argument that the differences reflect more general conventions of political argumentation in the two countries.

Moreover, it is not only the typically 'civic' actors, civil society organisations, and democratically elected politicians who use civic justifications in France. Economic organisations also resort to civic justifications, and businessmen and a right-wing president call for regulation of climate change by states or new international organisations. Similarly in the USA, in addition to businesses that are the obvious users of market justifications, civic organisations and a (somewhat) left-leaning president opt for justifications in terms of monetary value. This, again, supports our argument that the differences we find are not due to, say, the sourcing strategies of the journalists, but reflect the differences between the two political cultures more generally. 
We drew our hypotheses from studies on the differences of national repertoires of justifying political arguments on various issues and found that many of these differences are also visible in the media debates on climate change. Thus, we have argued that the differences found here are not only about what happen to be the current ways of framing climate policy arguments, but rather, reflect more deep-seated differences in national political cultures.

What is the significance of these findings to the global politics of climate change? Disagreements in the global politics of climate change, therefore, are not just about the details of particular policy proposals, but also about moral principles and understandings of what is worthy. Understanding these national differences in the media debate may also help in understanding disagreement and the current political stalemate in the global political arena.

With the rapid economic development and consequential rise in GHG emissions in countries like China, Brazil, India, and South Africa, the focus of global climate politics has increasingly shifted from the US-EU axis analysed in this paper to the opposition between the emerging economies of the Global South and the longindustrialised countries of the North. Future research on climate change and the media, therefore, would do well to move beyond single-country case studies and paired comparisons and to include the emerging economies in comparative research designs. In particular, questions of moral evaluation, central to many present North-South disagreements over climate policy, should be investigated from this kind of wider comparative perspective.

\section{Acknowledgements}

We would like to thank Salla Korpivaara for her assistance in coding parts of the research material. We are also grateful to Laurent Thévenot, the members of the Helsinki Research Group for Political Sociology and participants of the Environment, Technology and Sustainable Development 2014 conference for their comments on earlier drafts of this paper. Our research has been funded by the Academy of Finland and the Kone Foundation.

\section{References}

Antilla, L. (2005) 'Climate of skepticism: US newspaper coverage of the science of climate change', Global Environmental Change, Vol. 15, No. 4, pp.338-352.

Aykut, S.C., Comby, J.B. and Guillemot, H. (2012) 'Climate change controversies in French mass media 1990-2010', Journalism Studies, Vol. 13, No. 2, pp.157-174.

Boltanski, L. and Thévenot, L. (1999) 'The sociology of critical capacity', European Journal of Social Theory, Vol. 2, No. 3, pp.359-377, doi:10.1177/136843199002003010.

Boltanski, L. and Thévenot, L. (2006) On Justification: Economies of Worth, New Ed., Princeton University Press, Princeton.

Boykoff, M.T. and Boykoff, J.M. (2004) 'Balance as bias: global warming and the US prestige press', Global Environmental Change, Vol. 14, No. 2, pp.125-136.

Boykoff, M.T. and Boykoff, J.M. (2007) 'Climate change and journalistic norms: a case-study of US mass-media coverage', Geoforum, Vol. 38, No. 6, pp.1190-1204. 
Brossard, D., Shanahan, J. and McComas, K. (2004) 'Are issue-cycles culturally constructed? A comparison of French and American coverage of global climate change', Mass Communication \& Society, Vol. 7, No. 3, pp.359-377.

Caillaud, S., Kalampalikis, N. and Flick, U. (2011) 'The social representations of the Bali climate conference in the French and German media', Journal of Community \& Applied Social Psychology, Vol. 22, No. 4, pp.363-378.

Camus-Vigué (2000) 'Community and civic culture: the rotary club in France and the United States', in Lamont, M. and Thévenot, L. (Ed.): Rethinking Comparative Cultural Sociology. Repertoires of Evaluation in France and the United States, Cambridge University Press, Cambridge.

Carvalho, A. (2007) 'Ideological cultures and media discourses on scientific knowledge: re-reading news on climate change', Public Understanding of Science, Vol. 16, No. 2, p.223.

Dirikx, A. and Gelders, D. (2010) 'To frame is to explain: A deductive frame-analysis of Dutch and French climate change coverage during the annual UN conferences of the parties', Public Understanding of Science, Vol. 19, No. 6, pp.732-742, doi:10.1177/0963662509352044.

Gladarev, B. and Lonkila, M. (2013) 'Justifying civic activism in Russia and Finland', Journal of Civil Society, Vol. 9, No. 4, pp.375-390.

Goodman, J. (2009) 'From global justice to climate justice? Justice ecologism in an era of global warming', New Political Science, Vol. 31, No. 4, pp.499-514.

IPCC (2007) Climate Change 2007: Synthesis Report. Contribution of Working Groups I, II and III to the Fourth Assessment Report of the Intergovernmental Panel on Climate Change [Core Writing Team, Pachauri, R.K and Reisinger, A. (Eds.)], IPCC, Geneva, Switzerland, 104 pp.

Jasper, J. (1990) Nuclear Politics: Energy and the State in the United States, Sweden, and France, Princeton University Press, Princeton.

Jurdant, B. and Poupardin, E. (2010) 'Science, politics and the media: the climate gate disputes in France', PCST-2010-Proceedings, Retrieved from http://halshs.archives-ouvertes.fr/hal$00662828 /$

Koopmans, R. (2002) Codebook for the Analysis of Political Mobilization and Communication in European Public Spheres, Available at http://europub.wzb.eu/Data/Codebooks\%20 questionnaires/D2-1-claims-codebook.pdf

Koopmans, R. and Statham, P. (1999) 'Political claims analysis: integrating protest event and political discourse approaches', Mobilization, Vol. 4, No. 2, pp.203-221.

Koopmans, R. and Statham, P. (2010) The Making of a European Public Sphere: Media Discourse and Political Contention, Cambridge University Press, New York.

Lafaye, C. and Thévenot, L. (1993) 'Une justification écologique? Conflits dans l'aménagement de la nature', Revue Française de Sociologie, Vol. 34, No. 4, pp.495-524, doi:10.2307/3321928.

Lamont, M. (1992) Money, Morals and Manners: The Culture of the French and the American Upper Middle-Class, The University of Chicago Press, Chicago.

Lamont, M. and Thévenot, L. (Eds.) (2000) Rethinking Comparative Cultural Sociology: Repertoires of Evaluation in France and the United States, Cambridge University Press, Cambridge.

Luhtakallio, E. (2012) Practicing Democracy. Local Activism and Politics in France and Finland, Palgrave Macmillan, Basingstoke.

Luhtakallio, E. and Ylä-Anttila, T. (2011) 'Julkisen oikeuttamisen analyysi sosiologisena tutkimusmenetelmänä [Justifications Analysis as a sociological research method]', Sosiologia, Vol. 48, No. 1, pp.34-51.

McCright, M. and Dunlap, E. (2000) 'Challenging global warming as a social problem: an analysis of the conservative movement's counter-claims', Social Problems, Vol. 47, No. 4, pp.227-48.

McCright, M. and Dunlap, E. (2003) 'Defeating Kyoto: the conservative movement's impact on US climate policy', Social Problems, Vol. 50, No. 3, pp.348-73. 
Moody, M., Lafaye, C. and Thévenot, L. (2000) 'Forms of valuing nature: arguments and modes of justification in French and American environmental disputes', in Lamont, M. and Thévenot, L. (Eds.): Rethinking Comparative Cultural Sociology. Repertoires of Evaluation in France and the United States, Cambridge University Press, Cambridge.

Mormont, M. and Dasnoy, C. (1995) 'Source strategies and the mediatization of climate change', Media, Culture \& Society, Vol. 17, No. 1, pp.49-64, doi:10.1177/016344395017001004.

Parks, B.C. and Roberts, J.T. (2010) 'Climate change, social theory and justice', Theory, Culture \& Society, Vol. 27, Nos. 2-3, pp.134-166, doi:10.1177/0263276409359018.

Posner, E.A. and Weisbach, D. (2010) Climate Change Justice, Princeton University Press, New Jersey.

Reitan, R. and Gibson, S. (2012) 'Climate change or social change? Environmental and leftist praxis and participatory action research', Globalizations, Vol. 9, No. 3, pp.395-410.

Schmidt, A., Ivanova, A. and Schäfer, M. (2013) 'Media attention for climate change around the world: a comparative analysis of newspaper coverage in 27 countries', Global Environmental Change, Vol. 23, No. 5, pp.1233-1248.

Soltau, F. (2009) Fairness in International Climate Change Law and Policy, Cambridge University Press, Cambridge.

Stern (2006) The Economics of Climate Change. The Stern Review, Cambridge University Press, Cambridge.

Vetters, R., Jentges, E. and Trenz, H.J. (2009) 'Whose project is it? Media debates on the ratification of the EU Constitutional Treaty', Journal of European Public Policy, Vol. 16, No. 3, pp.412-430.

Ylä-Anttila, T. (2010) Politiikan paluu: globalisaatioliike ja julkisuus [The Return of Politics: The Global Justice Movement and the Public Sphere], Vastapaino, Tampere.

Zehr, S. (2009) 'An environmentalist/economic hybrid frame in US press coverage of climate change, 2000-2008', in Boyce, T. and Lewis J. (Eds.): Climate Change and the Media, Peter Lang Publishing, New York, pp.80-91.

\section{Notes}

${ }^{1}$ The codebook is available from the authors upon request.

${ }^{2}$ Our complete report of the reliability calculations can be found at http://bit.ly/clic-reliability. The calculations are made for the purposes of a more extensive research project on climate change and the media, and thus they contain several variables not used in the present article.

${ }^{3}$ The search terms were climate change/changement climatique OR global warming/rechauffement climatique OR greenhouse effect/effet de serre OR the city where the UN COP was being held at the moment, e.g., copenhagen/copenhague. The resulting articles that did not address the topic of climate change or climate politics were then removed manually from the sample.

${ }^{4}$ The only exception is the share of justice claims, where the difference between the countries narrows by two percentage points when we look at domestic actors only. This reflects the fact that justice claims are, in both countries, often put forward not by national players but by international civic organisations such as Oxfam International or intergovernmental organisations. 